\title{
単一運動単位の興舊の相対的闘値変動について
}

\author{
倉田博*

\section{THE RELATIVE THRESHOLD OF ACTIVATION OF SINGLE HUMAN MOTOR UNITS IN VOLUNTARY MUSCULAR CONTRACTION}

\author{
Hiroshi Kurata
}

In order to investigate the mechanism of activity of motor units, discharges of single human motor units in the $\mathrm{m}$. vastus medialis in voluntary contraction by use of electrodes inserted in the muscles were simultaneously recorded with the tension developed at the knee joint in its extension effort. The results were as follows.

1) The single spike discharges of single motor units were observed at the rate of $54.5-86.2 \%$, the total number of discharges being $100 \%$, when the knee extension effort was gradually increased and was abruptly decreased by the time of spike wave appearance on the Braun tube.

2) When the tension of knee extending force was maintained steadily, the longest consecutive discharge in a single motor unit was observed for more than 90 minutes.

3) The tension of knee extending force at the recruitment in a certain single motor unit recorded in 15 seconds interval was nearly constant within 30-60 minutes tested with certain fixed value for each motor unit except some fluctuation.

(J. Physical Fitness Japan 1972, $21: 176 \sim 182$ )

\section{緒言}

従来，随意運動に抢ける筋収縮はすべて強縮で あり，単収縮は反射による場合にのみ発現すると 言われている5 た場合に，随意的に単一のスパイクを発現し得る かどうかは，随意運動の調節という見地からは重 要な問題である。この問題について筋内埋入電極 を用いて検索を行なった。

また，随意運動時には運動単位は互に活動交代 をしながら活動していると言われている6778)。し かし，その活動交代がどのような様式で起ってい るかは検討の必要があるよ5に思われる。そこで 同じく筋内埋入電極を用い, 長時間単一の運動単 位の放電をとらえて，その様式を明らかにしょう と試みた。

先の単一運動単位に抢ける単収縮の問題の検討 の結果, 筋力を漸增していく時, ブラウン管面上 に現象波形でトリガーされたビームが掃引される のを見て筋を弛緩する場合に，かなり高い頻度で
単一の放電を記録し得た。そこでそれを指標にし， その時の筋力の時系列を記録した。その筋力の時 系列記録によって単一運動単位の相刘的な閾値变 動について検討した。

\section{実 験 方 法}

単一の運動単位の放電を記録するために, 直径 $100 \mu$ のポリウレタン絶縁銅線を 2 本接着して長 軸に直角に切断し，1/3 皮下注射針に通し 先端約 $2 \mathrm{~mm}$ を折り曲げて筋内に刺入した後注射針を抜 去した筋内埋入電極を用いた4)。入力は平衡入力 方式とし, 不関電極は直径 $10 \mathrm{~mm}$ の銀板電極 2 枚 に電極糊を充たして近傍の皮膚面上に貼布した。 また, 日本光電製の陰極線オシロスコープ VC$7 \mathrm{~A}$ (前置增幅器には生体電気用増幅器 AVB-2 及 び 2 現象用增幅器 AVM-2S 使用) 及び連続撮影 装置 PC-2B を使用した。AVB-2 の時定数は 0.003 秒とした。被験者は健康成人であり, 被験 筋には左右の $\mathrm{m}$. vastus medialis を用いた。被験 者は台に椅座し，下腿を膝関節が $90^{\circ}$ になるよう

\footnotetext{
* 東京慈恵会医科大学第一生理学教室 Department of Physiology, The Jikei University School of Medicine
} 
に下垂させて随意的膝伸展を行ない，足関節部に 発生する張力をストレインゲージでとらえ筋放電 と同時記録した。張力記録のためには日本光電製 ポリグラフ RM-150 及び歪計用前置增幅器 RP-3 またはマノメーター MP-3A を用い, VC-7A の AVM-2S に入力して撮影記録を行った。

単一運動単位に招いて随意的に単一の放電を発 現させ得るかどらかの検討のためには次のような 方法をとった。電極を単一の運動単位のスパイク が記録できる位置に安定させて，陰極線オシロス コープを現象波形でトリガー掃引した。トリガー レベルは他の運動単位のスパイク等の小さい電位 によってはトリガーされないで，対象とする運動 単位のスパイクの大きい電位では十分トリガーさ れるようにレベルを設定した。ブラウン管に掃引 が行なわれていない状態から徐々に膝関節の伸展 張力を増大させていき，スパイクによって掃引が 行なわれるのを見て筋を弛緩し，スパイクの記録 を行なった。掃引速度はブラウン管面上で $0.2 \mathrm{~m}$ $\mathrm{sec} / \mathrm{cm}$ とし，現象波形によっては 0.5 及び $1.0 \mathrm{~m}$ $\mathrm{sec} / \mathrm{cm}$ にした。また, 2 個の運動単位の活動電位 を同時にとらえ, ブラウン管のビームを止めてオ シロペーパーを $100 \mathrm{~mm} / \mathrm{sec} て ゙$ 送って張力と同時 記録した。

運動単位の活動交代の様式の検討のためには同 じく電極を単一の運動単位のスパイクが記録でき る位置に安定させ，ブラウン管のビームの掃引を 止め,オシロペーパーを 5 及び $10 \mathrm{~mm} / \mathrm{sec}$ の速度 で送ってスパイクを張力と同時記録した。また，

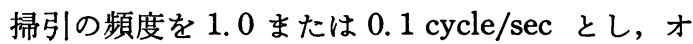
シロペーパーを掃引の方向に対して直角方向に， 送り速度 $10.0 ， 2.5$ または $1.0 \mathrm{~mm} / \mathrm{sec} て ゙$ 送って 長時間の記録を行なった。

単一運動単位の相対的な閾値変動を検討するた めに，上述の単一スパイクを記録する方法により 測定を約 15 秒間隔で 30〜60 分間行なった。膝関 節伸展張力の利得はブラウン管面上で $0.5 \mathrm{~kg} / \mathrm{cm}$ とした。

\section{実 験 成 績}

陰極線オシロスコープを現象波形によるトリガ 一掃引にして, 徐々に膝関節の伸展張力を增大さ せ，掃引されるのを見て張力を减少させると，単
Table 1. The rate of single spikes observed against the total number of spikes in various single motor units.

\begin{tabular}{c|c|c|c}
\hline unit & N & $\begin{array}{c}\text { number of } \\
\text { single spikes }\end{array}$ & $\%$ \\
\hline a & 276 & 238 & 86.2 \\
b & 237 & 182 & 76.8 \\
c & 118 & 90 & 76.3 \\
d & 109 & 82 & 75.2 \\
e & 232 & 150 & 64.7 \\
$\mathrm{f}$ & 102 & 65 & 63.7 \\
g & 114 & 70 & 61.4 \\
h & 128 & 78 & 60.9 \\
i & 161 & 89 & 55.3 \\
j & 121 & 66 & 54.5 \\
\hline
\end{tabular}

一のスパイク放電が記録できた。各運動単位から 得られた種々の波形の記録を図 1 に例示した。測 定は約 15 秒の間隔で行なった。二発以上のスパ イクが記録される場合るあったが，注意深く行な 万と単一のスパイクの記録される割合は表 1 に示 す如く54.5〜86.2\%に及んた。また， 2 個の運動 単位の活動電位を同時に記録した例を図 2 に示し た。一方のスパイク放電が持続しているとき，他 方の単一スパイク放電が観察された。

単一の運動単位のスパイク放電が記録できる状 態で，持続的に放電が続くほぼ一定の張力を保持 すると, unit A において 90 分以上にわたってス パイク放電が持続した（図 3 )。また表 2 に示すよ 5に放電している時間が大部分で，時々少時放電 を休止する例も観察された。これらの場合の持続 張力は $0.5 \sim 4.0 \mathrm{~kg}$ であり, unit A, B に打ける 興奮に参加する時点の張力は $0.2 \mathrm{~kg}$, unit Cでは $1.0 \mathrm{~kg}$ であった。

単一運動単位の最初のスパイクが発現する時点 の膝関節伸展張力を約 15 秒の間隔で記録し, 各運 動単位についてその時の張力を時間に対してプロ ットすると図 4 に示す如くなる。この場合, 同一 波形のるのだけをプロットするように注意した。 unit $1,2,3$ は $0.5 \mathrm{~kg}$ 以内であり, unit $4,5,6$ は 約 $0.5 \mathrm{~kg}$, unit 7 は約 $1.5 \mathrm{~kg}$, unit 8,9 は約 $3 \mathrm{~kg}$, unit 10 は約 $4 \mathrm{~kg}$ を中心としており，動摇が見ら れた。unit 1,2, 3 は動摇が小であり, unit 7, 9, 10 は比較的変動が大であった。unit $4,5,6$ では 時々急激に值が増大した。unit 1,2,3 では 40〜 

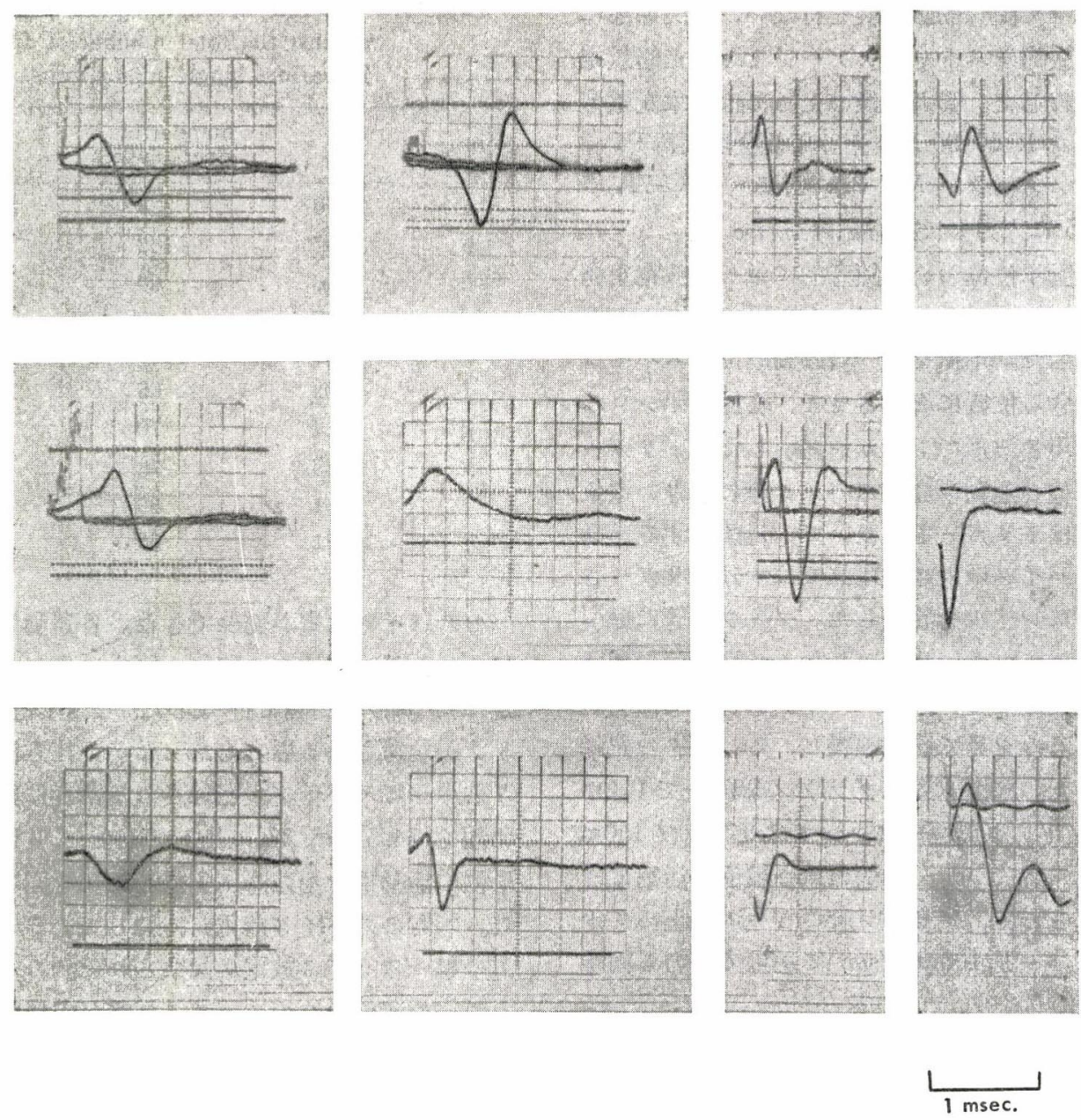

Fig. 1. Samples of spike forms recorded during the single spike discharges in different single motor units.

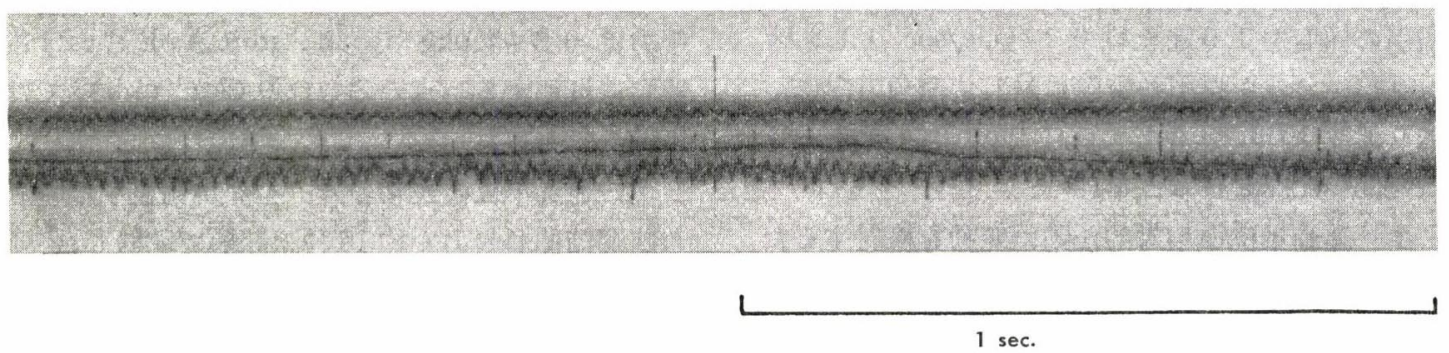

Fig. 2. Spike discharges of two single motor units and muscular tension simultaneously recorded.

60 分間にわたりほぼ一定した值を得た。また， unit 3 では 60 分間の測定に続き, 約 $5 \mathrm{~kg}$ の張力 を10 分間持続負荷した後測定すると動摇の幅が 増大した。

な和，この条件に和ける膝関節伸展最大筋力は
左右とも約 $60 \mathrm{~kg}$ であった。大腿四頭筋が実際に 発揮した張力はレントゲン撮影により算出した結 果，その約 7.6 倍になる。 

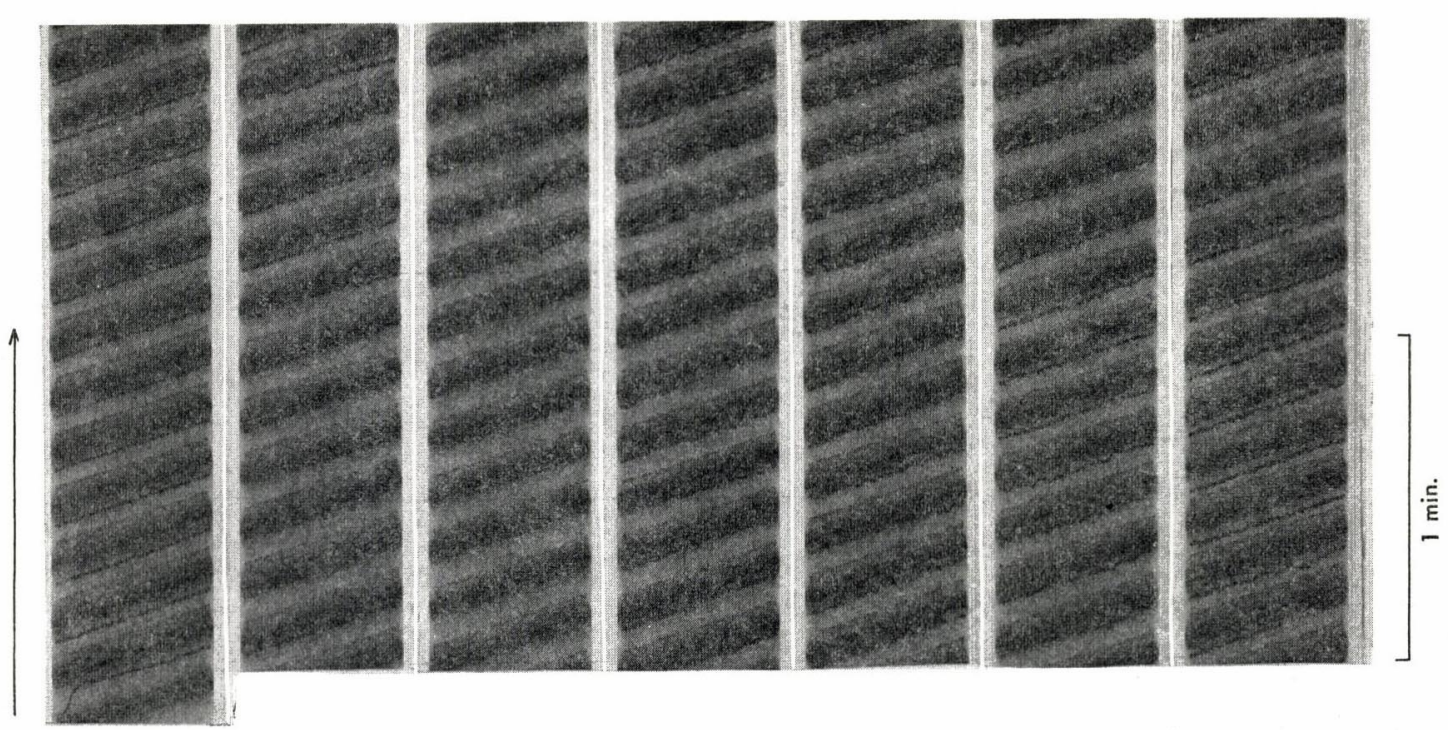

$0 \sim 2$

$15 \sim 17$

$30 \sim 32$

$45 \sim 47$

$60 \sim 62$

$75 \sim 77$

$90 \sim 92 \mathrm{~min}$.

Fig. 3. Continuous recording of spike discharges in a single motor unit.

Table 2. Time length of spike discharge in various single motor units.

\begin{tabular}{|c|c|c|c|c|c|c|c|c|c|c|c|c|c|c|c|c|c|}
\hline unit & $\begin{array}{l}\text { tension of } \\
\text { recruitment }\end{array}$ & $\begin{array}{l}\text { sustained } \\
\text { tension }\end{array}$ & $\mathrm{f}$ & $\mathrm{s}$ & f & $\mathrm{s}$ & f & $\mathrm{s}$ & $\mathrm{f}$ & s & $f$ & $\mathrm{~s}$ & f & $\mathrm{s}$ & f & $\mathrm{s}$ & f \\
\hline A & $0.2 \mathrm{~kg}$ & $1.0 \sim 1.5 \mathrm{~kg}$ & $94^{\prime} 30^{\prime \prime}$ & & & & & & & & & & & & & & \\
\hline B & 0.2 & $0.5 \sim 1.0$ & $53^{\prime} 30^{\prime \prime}$ & & & & & & & & & & & & & & \\
\hline $\mathrm{C}$ & 1.0 & 1.5 & $20^{\prime} 30^{\prime \prime}$ & & & & & & & & & & & & & & \\
\hline $\mathrm{D}$ & & 3.0 & $3^{\prime} 27^{\prime \prime}$ & $21^{\prime \prime}$ & $6^{\prime} 57^{\prime \prime}$ & $2^{\prime \prime}$ & $6^{\prime \prime}$ & $10^{\prime \prime}$ & $14^{\prime} 15^{\prime \prime}$ & $4^{\prime \prime}$ & $42^{\prime \prime}$ & $13^{\prime \prime}$ & $2^{\prime} 14^{\prime \prime}$ & $40^{\prime \prime}$ & $38^{\prime \prime}$ & & $2^{\prime} 00^{\prime \prime}$ \\
\hline $\mathrm{E}$ & & $2.0 \sim 3.0$ & $9^{\prime} 25^{\prime \prime}$ & & & & & & & & & & & & & & \\
\hline $\mathrm{F}$ & & 4.0 & $8^{\prime} 22^{\prime \prime}$ & & & & & & & & & & & & & & \\
\hline
\end{tabular}

$f$ : period of time of firing

$\mathrm{s}$ : period of time of silence

\section{実験成績に対する考察}

随意運動に抢ける筋収縮は一般に強縮であると 言われるが5)，徐々飞筋力を增大していき，スパ イクの発現を合図に筋を弛緩する時単一運動単位 飞和いて単一のスパイク放電が記録できる。した がって時実等9)10) が随意活動時に短母指外転筋で 単収縮を認めたことと合せ考えると, 運動単位の レベルでは随意運動に括いて単一のインパルスに よる単収縮が生じることがあるものと思われる。 このことは筋力の随意調節が極めて微妙に遂行さ れ得ることを示唆している。

単一運動単位のスパイク放電が $90,50,20,14$, 9 及び 8 分以上持続し得たが, これらの運動単位
は少くともとれ以内の時間では他の運動単位との 活動交代を起していない。これらの場合の保持し た膝関節伸展張力は $0.5 \sim 4.0 \mathrm{~kg}$ なので, 最大筋 力が約 $60 \mathrm{~kg}$ であるのに対して, このよ5な弱収 縮時には比較的長時間にわたって放電が持続され るものと思われる。弱収縮時に活動している運動 単位の数は少ないにもかかわらず, 活動交代は相 当長時間起り難いことが推定される。既に Smith ${ }^{6)}$, 時実等7)8) によって上腕二頭筋及び下肢抗重力 筋について弱収縮時には 10１4 分にわたって活 動交代を生じないことが報告されているが，上記 の結果はこれ等の成績を裏書きする。しかし 90 分にわたって活動交代をしない例が認められたこ とは留意価するものと考光る。また，一定の筋 

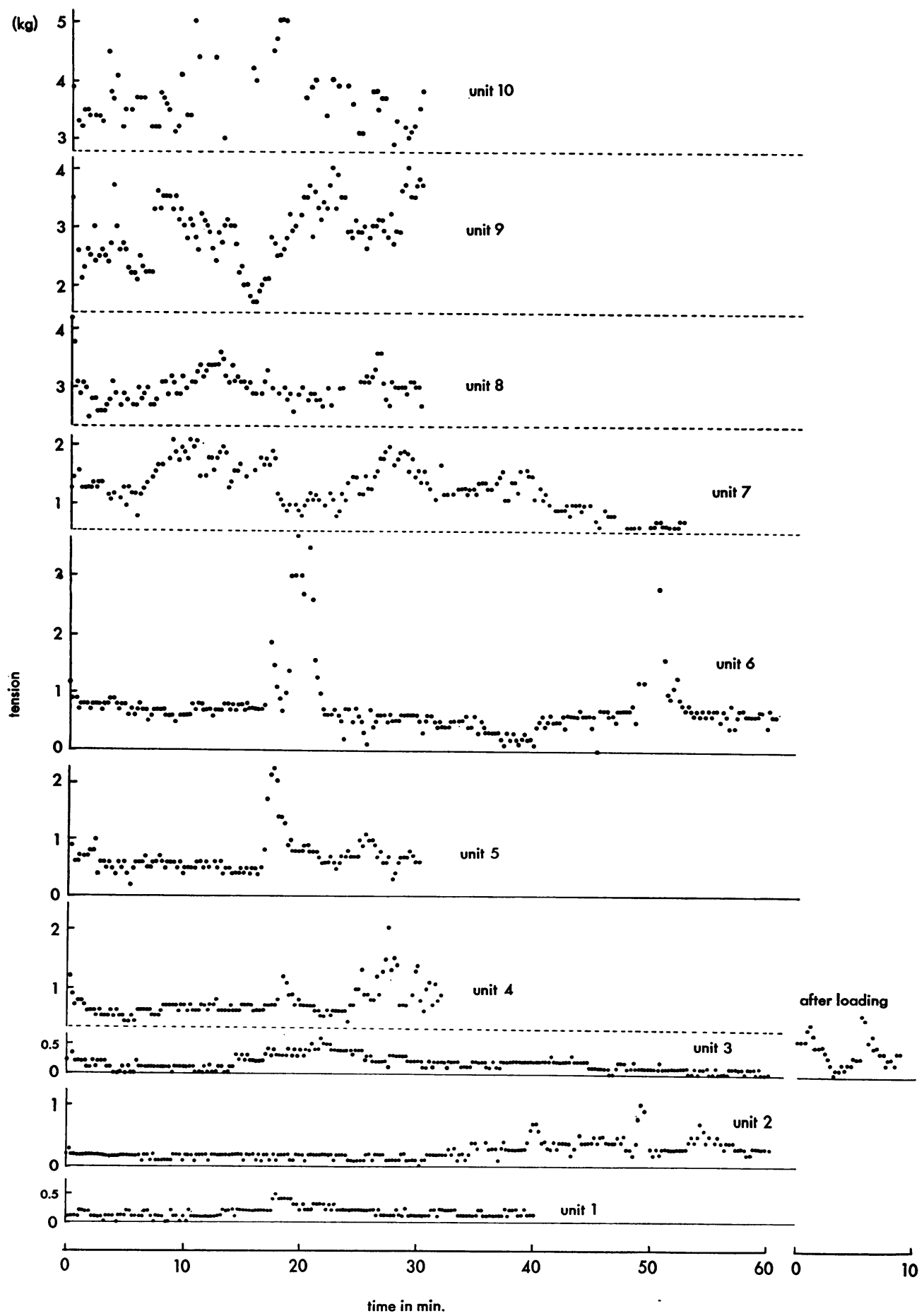

Fig. 4. Muscular tension in relation with moments of recruitment of single motor units. 
力を保持しているにもかかわらず，時々少時放電 が休止したが，この時にはその運動単位の $\alpha$ 運動 神経細胞の相対的な閾值が上䄯したことも考えら れる。

対象とした単一の運動単位が活動に参加する時 の張力の時系列は, 動摇を示しながらもほぼ一定 している例が多い。そして, 各運動単位はそれぞ れほぼ特定の值を持っているように思われる。こ れは各運動単位がそれぞれの持つ特定の筋力值に 達したところで活動に参加するものとも考兄られ る。Kugelberg 等 ${ }^{122)}$, 時実等 ${ }^{8)}$ とよって活動に参 加する時の収縮の程度に運動単位による差異があ ることが述べられているが，その值がこのように 長時間にわたって特定値を示すことは注目に価す るものと考える。この值に動摇が見られるのは, $\alpha$ 運動神経細胞への興奮性及び抑制性インパルス の量的変動によるところの $\alpha$ 運動神経細胞の興奮 の他の $\alpha$ 運動神経細胞に対する相対的な閾值の变 動であることも考えられる。この変動は相対的閾 值が大きい方が大である傾向が見られ，一定の筋 力を保持する筋力調節の際の誤差が目標とする筋 力の增大に伴なって增大する ${ }^{3) 4}$ ことと何等かの 関係があるようにも思われるが，今後の検討を要 する問題であると思われる。unit 4,5,6 において 時々值が急激に増大したが，この大きい変動が何 に起因したかは不明である。この場合その值以下 ではその運動単位は興奮しない筈であるから,一 定の筋力を発揮している時このような興奮の相対 的閾値の上升が起ればその運動単位はスパイク放 電を停止することが推定される。運動単位の活動 交代は, その根抵に各運動単位のこのような相対 的閾值変動が存在することによって発現している ものと思われる。

この実験に打いては, 筋力増减に伴なら電極の 動きによるところの成績の不確実さの問題が払拭 できないけれども，筋力の増大に伴なって振幅の 增大寸る場合には運動単位の筋線維束と電極との 位置が変動したものと思われる。しかし筋力の增 大にもかかわらず振幅が变化しない場合には電極 の位置は变らなかったものと考えられる。筋線維 束に放電があるにもかかわらず電極にとらえられ ず，ある筋力に達したところで突然不連続的にと らえられるよ5になって，以後筋力を増大しても
振幅に変化がないとい5ことは一応考え難い。単 一スパイクを記録するに先立って，筋力增大に伴 なら振幅の漸增のないことを記録確認し，また数 発のスパイクを重斌撮りして異なった波形のもの によってトリガーされず，またその波形では十分 にトリガーされることを確認した後測定を行なっ たので，電極の動きによる成績の誤差は極力抑え られていると思われる。また図1に見られるよう に運動単位が異なると波形が種々变化するが，同 一波形のものだけを問題にしたので他の運動単位 との混同はまずないものと思われる。

\section{摘要}

運動単位の特性を検討することを目的として， 人の $\mathrm{m}$. vastus medialis の単一運動単位の放電を 筋内埋入電極でとらえて滕関節伸展張力と同時記 録し，次のような結果を得た。

1）徐々に張力を增大させ，ブラウン管の現象 波形を見て張力を減少させる時, 単一のスパイク 放電が 54.5 86.2\%の割合で記録された。

2) ほぼ一定の張力を保持する時, 単一運動単 位のスパイク放電が 90 分以上持続する 例が記録 された。

3）単一運動単位の最初のスパイクが発現する 時の張力を䄪 15 秒の間隔で 記録すると，30６0 分間にわたって多少の動摇を示しながらもほぼ特 定張力値を示す unit が多く観察された。

擱筆に当り, 終始御懇篤なる御指導, 御校閲を睗 わった名取教授に深甚の謝意を表する。 （受付 昭和 47 年 10 月 25 日）

\section{文}

\section{献}

1) Kugelberg, E. and Skoglund, C.R. (1946) Responses of single human motor units to electrical stimulation. J. Neurophysiol. 9, 391 $-398$

2) Kugelberg, E. and Skoglund, C.R. (1946) Natural and artificial activation of motor units-a comparison. J. Neurophysiol. 9, 399412

3）倉田 博, 馬詰良樹, 柳本昭人, 森下芳郎, 山 本直道 (1970) 筋力の調節能力について。 体力 科学, $19,36-46$

4）倉田 博, 柳本昭人(1971) 筋力の調節時の筋 
電図について，体力科学，20, 118

5) 名取礼二(1968) 現代スポーツ生理学, 初版, 運動に関与する身体各部の働き, 日本体育社, 東京, 1-36

6) Smith, O.C. (1934) Action potentials from single motor units in voluntary contraction. Amer. J. Phrsiol. 108, 629-638

7) 時実利彦, 小片 保, 近藤達子, 田中宜子 (1951) 抗重力筋 antigravity muscles に就て Neuromuscular unit の活動様式に関する研究 (5),
体力科学，1，61-66

8）時実利彦，津山直一(1951) 筋電図とその臨床 的応用一総覧一，東京医学誌，59，62-87

9）時実利彦(1955） 人間の骨格筋の機能分化 I運動の Corticalization と Spinalization一, 科 学, 25, 229-233

10）時実利彦（1955）人間の骨格筋の機能分化 II 一運動の Corticalization と Spinalization一. 科学, 25, 291-297

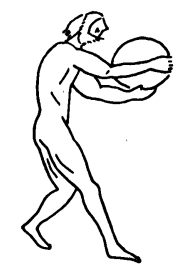

